\title{
Cleaner production of soapstone in the Ouro Preto region of Brazil: a case study
}

\author{
M.L.M. Rodrigues, R.M.F. Lima* \\ Department of Mining Engineering, Federal University of Ouro Preto, Ouro Preto, MG, Brazil
}

\section{A $\quad$ R $T$ T I C C L E I I N F}

\section{Article history:}

Received 1 October 2011

Received in revised form

23 March 2012

Accepted 25 March 2012

Available online 3 April 2012

\section{Keywords:}

Soapstone residues

Talc

Industrial mineral

Residue characterisation

Residue recovery

Flotation

Magnetic separation

Leaching process

\begin{abstract}
A B S T R A C T
Soapstone is a metamorphic rock that is used for ornamental and construction purposes. Rock recovery during the exploitation process is low. Quarries in the state of Minas Gerais in Brazil sell small and lowquality blocks to artisans, who produce pans and souvenirs. This activity constitutes the main economic activity in several places within the Ouro Preto region, such as Santa Rita. Soapstone artisan workshops produce a large quantity of powder (approximately 10-15\% rock recovery), which is discarded carelessly, often causing environmental problems. The objective of this study was to characterise and purify soapstone powder from the workshop of an artisan who works exclusively with rocks from BandeirasSanta Rita de Ouro Preto in order to identify potential applications for the residues and purified products. First, the mineralogical composition was determined by X-ray diffractometry, the size distribution was determined by sieving and the chemical composition of the residue was determined by inductively coupled plasma-optical emission spectroscopy (ICP-OES). Next, purification tests were performed by magnetic separation for fraction sizes larger than $74 \mu \mathrm{m}$. Fraction sizes smaller than $74 \mu \mathrm{m}$ were purified by flotation and leaching with hydrochloric acid. This research shows that it is possible to recover almost all residues of both small and large size distributions for use as insecticide filler. In addition, it is possible to recover $100 \%$ and $96 \%$ of fraction sizes larger and smaller than $74 \mu \mathrm{m}$, respectively, for use in the paper industry (wallpaper and packaging). For more valuable applications, it is necessary to leach the purified material from flotation using hydrochloric acid. In addition to decreasing the environmental impact of soapstone powder discharge, it is possible for soapstone artisans to sell this powder for a profit, whether it is purified or not.
\end{abstract}

(c) 2012 Elsevier Ltd. All rights reserved.

\section{Introduction}

Soapstone is a metamorphic rock that comes from primitive sedimentary limestone rocks or from basic/ultrabasic igneous rocks by hydrothermal and metasomatic alteration of magnesium silicate. The rock texture can be powder, massive or compact and lamellar (Lara Filho, 1997). To be classified as soapstone, the proportion of the mineral talc in the rock must be above $35 \%$, and either the proportion of the minerals chlorite, quartz, calcite, dolomite, magnesite, tremolite, amphibole and hematite must be above 25\% (Kuzvart, 1984; Pinheiro, 1973). Talc and soapstone are often used synonymously (Skinner et al., 1997).

Talc $\left.\left(\mathrm{Mg}_{3}\left(\mathrm{SiO}_{4}\right)_{10}\right)(\mathrm{OH})_{2}\right)$ is a magnesium silicate hydrate made up of $31.7 \% \mathrm{MgO}, 63.5 \% \mathrm{SiO}_{2}$ and $4.8 \% \mathrm{H}_{2} \mathrm{O}$ (Skinner et al., 1997). It is a filler-type industrial mineral that is used in many products, including paint, paper, ceramics, plastic, roofing products, rubber,

\footnotetext{
* Corresponding author. Departamento de Engenharia de Minas, Universidade Federal de Ouro Preto, Campus Universitário, Morro do Cruzeiro, S/N, CEP: 35400000, Ouro Preto, MG, Brasil. Tel.: +55 313559 1590; fax: +55 3135591593.

E-mail address: rosa@demin.ufop.br (R.M.F. Lima).
}

cosmetics, pharmaceutics, insecticide, explosives, soap, candles, textiles and cereal polishing (rice, corn and barley). For each application, the talc must have certain properties and characteristics in terms of size distribution, morphology, mineralogy, purity, and other factors (Roe, 1975; Pontes and Almeida, 2008; Pogrebenkove et al., 1997 and Nkoumbou et al., 2008). Soapstone rock is often used as building stone and dimension stone. Fig. 1 presents the main Brazilian deposits of talc, including soapstone, which occurs in the states of Minas Gerais (MG), Goiás (GO) and Bahia (BA).

In the Ouro Preto region of Brazil, located in Minas Gerais State, there are several soapstone quarries that exploit this rock as dimension stone. These places have rich deposits of talc that are extracted as by-products and sold to ceramic industries. The rough blocks are exported to European and North American countries, where they are cut into building stones. Currently, the annual production of soapstone in Bandeiras at Ouro Preto region is 4800 tons of soapstone and 2400 tons of talc.

During the exploitation of dimension stones, such as soapstone, only $30 \%$ of the rock is recovered. The remaining $70 \%$ is composed of small blocks that are used in artisan workshops, where pans and 
souvenirs are produced. In the production of pans, for example, the recovery of rock is approximately $10 \mathrm{wt} \%$ (Santos, 2009), which means that the global recovery of soapstone exploited in quarries is only $40 \mathrm{wt} \%$. Approximately $60 \mathrm{wt} \%$ of the rock is discharged as residue. Fig. 2 shows the main activities performed in a typical soapstone quarry in Santa Rita de Ouro Preto and the products that are sold to local artisans. Details of the production processes for souvenirs and pans are presented. A saw is applied to cut the rock and after a wood lathe is used to make and polish the produced objects. The large quantity of soapstone powder discharged from artisan workshops is also shown.

Lima et al. (2009) performed a technological characterisation of soapstone samples (Fig. 2(D)) used in artisan workshops from five different soapstone quarries in the Bandeiras region of Santa Rita Ouro Preto. The minerals were identified using optical microscopy, X-ray diffraction and scanning Electron Microscopy with an Energy Dispersive System (SEM/EDS). The following minerals were found: silicates [talc $\left(\mathrm{Mg}_{3}\left(\mathrm{Si}_{4} \mathrm{O}_{10}\right)(\mathrm{OH})_{2}\right)$, chlinoclore $((\mathrm{Mg}$, $\mathrm{Fe})(\mathrm{Si}, \mathrm{Al})_{4} \mathrm{O}_{10}(\mathrm{OH})_{8}$, phlogopite $\left(\mathrm{KMg}_{3}\left(\mathrm{Si}_{3} \mathrm{Al}\right) \mathrm{O}_{10}(\mathrm{~F}, \mathrm{OH})_{2}\right)$, tremolite/ actinolite $\left(\mathrm{Ca}_{2} \mathrm{Mg}_{5}\left(\mathrm{Si}_{8} \mathrm{O}_{22}\right)(\mathrm{OH})_{2} / \mathrm{Ca}_{2}\left(\mathrm{Mg}_{2} \mathrm{Fe}^{++}\right)_{5} \mathrm{Si}_{8} \mathrm{O}_{22}(\mathrm{OH})_{2}\right)$ and orthoclase $\left(\mathrm{K}\left(\mathrm{AlSi}_{3} \mathrm{O}_{8}\right)\right.$ ], carbonates [magnesite $\left(\mathrm{MgCO}_{3}\right)$ and dolomite $\left(\mathrm{CaMg}\left(\mathrm{CO}_{3}\right)_{2}\right)$ ], sulphides [pyrite $\left(\mathrm{FeS}_{2}\right)$, arsenopyrite (FeAsS) and pentlandite $\left.\left((\mathrm{Fe}, \mathrm{Ni})_{9} \mathrm{~S}_{8}\right)\right]$, oxides [magnetite $\left(\mathrm{Fe}_{3} \mathrm{O}_{4}\right)$ /hematite $\left(\mathrm{Fe}_{2} \mathrm{O}_{3}\right)$ and ilmenite $\left.\left(\mathrm{FeTiO}_{3}\right)\right]$. The apparent porosities of the soapstone rock samples were between 0.3 and $0.4 \%$, and the apparent water absorption was approximately $0.11 \%$. The Rockwell hardness of the samples was of a high range (73-84). This variability was attributed to the mineralogical heterogeneity on the faces analysed. The uniaxial compressive strength of the rock samples was between 20 and $25 \mathrm{MPa}$, and rupture occurred on the first or second cycles of the thermal tests.

The density of soapstone powder collected from the artisan workshop in the Bandeiras region varied from 2.73 to 2.83 (Rodrigues, 2010). The value of oil absorption of the purified product was $28.5(\mathrm{~g} / 100 \mathrm{~g})$. This value is within the specification for pigments and extenders (Rodrigues and Lima, 2011; Casanova et al.,

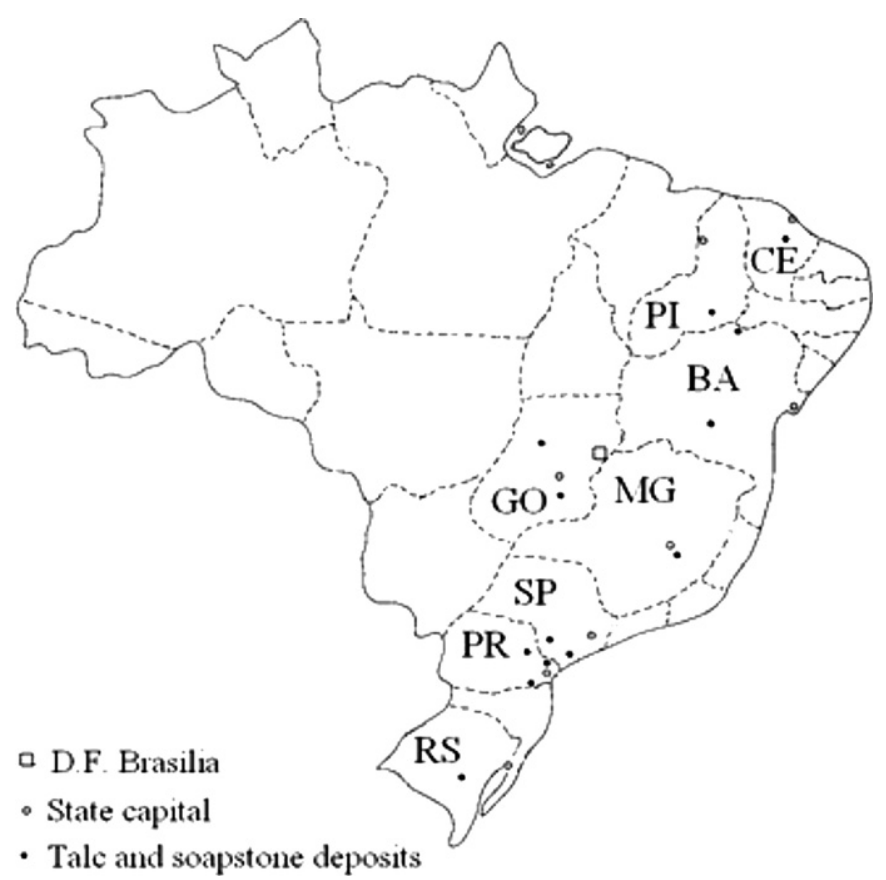

Fig. 1. Location of the talc deposits, including soapstone, in Brazil (CE - Ceará; PI Piauí; BA - Bahia; GO - Goiás; MG - Minas Gerais; SP - São Paulo; PR - Paraná; RS Rio Grande do Sul) (modified from Lara Filho, 1997).
2007). The morphology of the particles of purified talc was lamellar, as shown in Fig. 3.

This paper presents the characteristics and the main results of the purification tests carried out on the powder residues from an artisan workshop in Ouro Preto (Fig. 2(G)), the objective being to decrease the residues produced in this activity in order to find a classical application of this industrial mineral, as applications suggested by Driussi and Jansz (2006).

\section{Materials and methods}

Representative soapstone residues were collected in the workshop of an artisan who works exclusively with rocks originating from the Bandeiras region in Santa Rita de Ouro Preto. First, the powder residue was homogenised and quartered to obtain subsamples to determine the size distribution of the particles, as well as to perform mineralogical and chemical characterisation. The size distribution of the material was determined by wet sieving, and the fraction size $-74 \mu \mathrm{m}$ was determined by laser diffraction (Cilas 1064). Then, chemical analyses of size fractions greater and lower than $74 \mu \mathrm{m}$ were carried out using an Inductively Coupled Plasma - Optical Emission Spectrometer (Spectro model Ciros/CCD), except for $\mathrm{SiO}_{2}$ content, which was determined by the difference between $100 \%$ and the sum of all chemical element/ compound contents plus the loss on ignition (LOI).

The mineral composition of soapstone powder in both fraction size groups was performed using the X-ray diffraction (XRD) total powder method. The radiation used was $\mathrm{Cu} \mathrm{K \alpha}$. The goniometer velocity was $1.2^{\circ} / \mathrm{min}$, the counting time was of $58 \mathrm{~min}$ and data were collected from $2^{\circ}$ to $70^{\circ}$. A Rigaku model 3550 diffractometer was used. Mineral identification was performed using the pattern diffraction tool of the JADE 7.0 software package.

The purification of soapstone powder was realised using magnetic separation (Carpco Inc. model WHIMS 3X4L - serial 21097) and froth flotation (Cimaq cell). Leaching tests were performed with the concentrate of an optimised flotation test using hydrochloric acid $(\mathrm{HCl})$.

In the magnetic concentration (fraction size above $74 \mu \mathrm{m}$ ), the influence of the variable magnetic field intensity (3000; 4300 and $4900 \mathrm{G}$ ) on the mass recovery and whiteness of purified talc was studied. These experiments were replicated for each condition. The experimental procedure for the wet magnetic concentration tests consisted of the following steps. First, the magnetic field intensity was fixed to the desired value. Then, with the water tap open (flow rate of $670 \mathrm{~mL} \mathrm{~min}^{-1}$ ), a $100 \mathrm{~g}$ sample of dry soapstone powder was fed into the equipment. When it was observed that no particles were dropping into the non-magnetic bucket product, a new bucket was substituted in. Then, the equipment was turned off and the magnetic product was collected in the new bucket. Finally, both the magnetic and non-magnetic products were filtered, dried and weighed to calculate mass recovery. Finally, the products (magnetic and non-magnetic) were sampled to obtain subsamples for the determination of whiteness, CIE $\left(L^{*} a^{*} b^{*}\right)$ indices and chemical composition.

Purification of the soapstone powder (fraction size $-74 \mu \mathrm{m}$ ) was performed by flotation. Minitab 15 software was used to create and analyse the results of a fractional planning design (1/8) of eight factors (variables) on variable responses (mass recovery and whiteness). For each variable, two levels (minimum and maximum) were tested, as presented in Table 1 . This analysis was performed on a total of 32 flotation tests.

The following experimental procedure was used for the flotation tests. A mass of soapstone powder $(-74 \mu \mathrm{m})$ and the water quantities necessary to obtain the pulp density desired (10 or $20 \%$ ) were put into a 2 L cell cube. The cell speed was then adjusted ( 800 or 


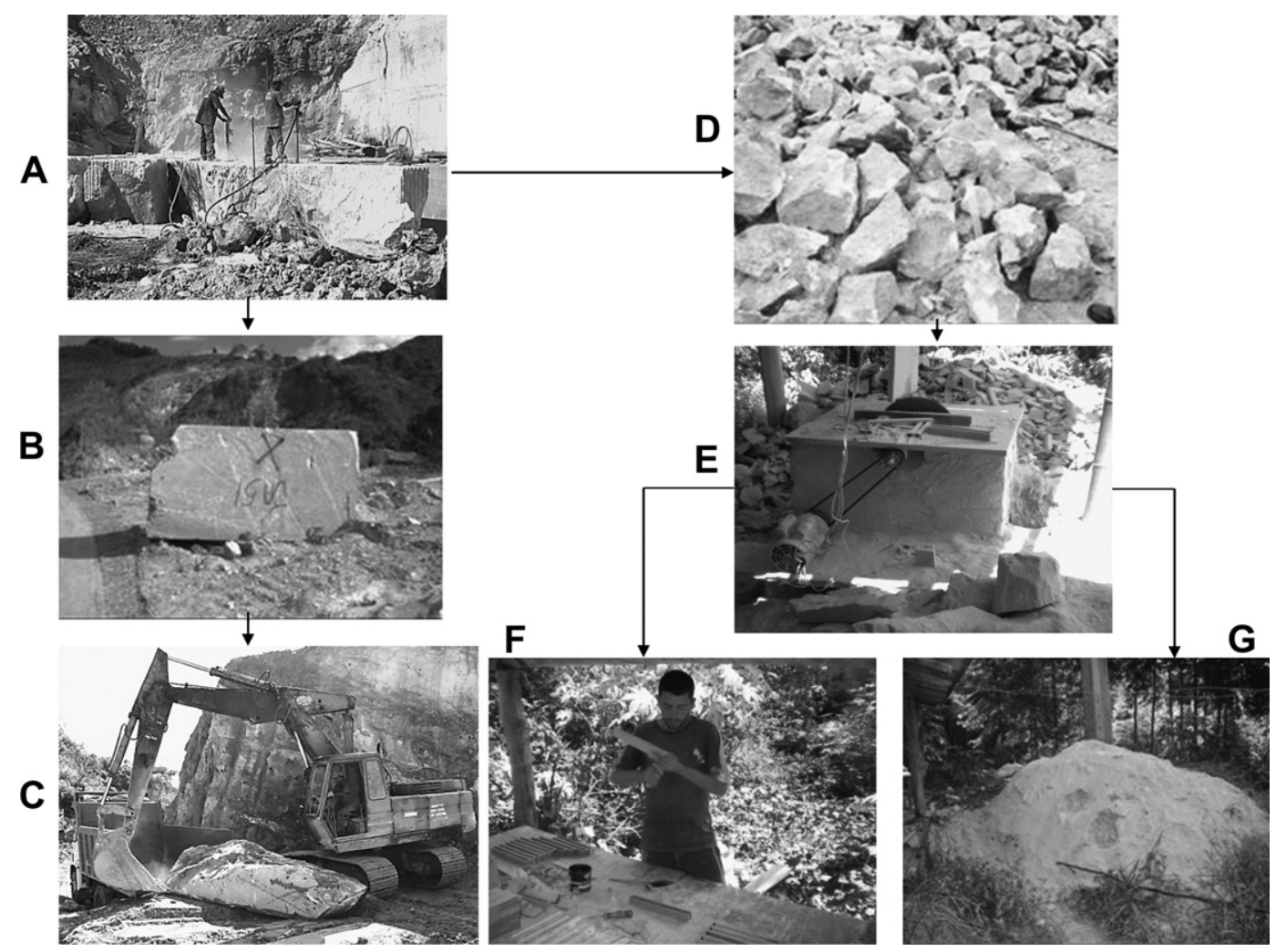

Fig. 2. Typical operations in a soapstone quarry, the commercial products and the souvenir production process in artisan workshops in the Ouro Preto region: (A) Detail of the exploitation operation in a soapstone quarry of Santa Rita de Ouro Preto, (B) A rough block of soapstone, (C) Transport of the rough block to be exported, (D) Small pieces of soapstone to be used in artisan workshops, (E) Saw applied to cut the objects produced in artisan workshops, (F) An artisan performing his work and (G) Soapstone powder

$1200 \mathrm{rpm})$. The air flow rates were 17.5 and $98 \mathrm{~mL} \mathrm{~s}^{-1}$ for cell speeds of 800 and $1200 \mathrm{rpm}$, respectively. After $2 \mathrm{~min}$, the depressant sodium silicate (500 or $1000 \mathrm{~g} / \mathrm{ton}$ ) was added and conditioned (5 or $10 \mathrm{~min}$ ). During conditioning with the depressant, the $\mathrm{pH}$ of the pulp was adjusted ( 7 or 11$)$. Next, kerosene (500 or $1000 \mathrm{~g} /$ ton $)$ was added to the pulp and conditioned (5 or $10 \mathrm{~min}$ ). The MIBC frother ( 75 or $150 \mathrm{~g} /$ ton) was then added to the pulp, and the pulp was conditioned ( 5 or $10 \mathrm{~min}$ ). The air tap was opened, and the froth was collected for approximately $6 \mathrm{~min}$. Both products

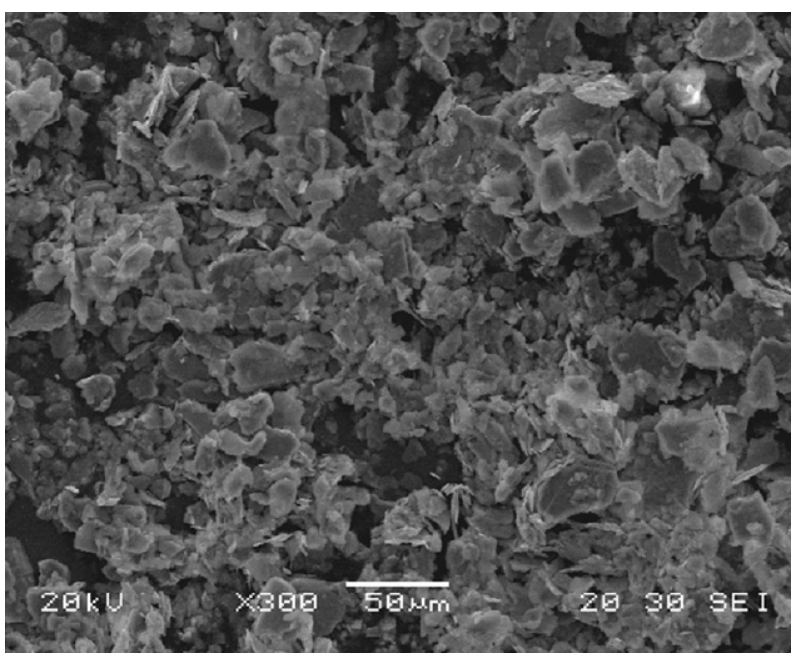

Fig. 3. Scanning electron microscope (SEM) image of purified talc from soapstone powder (Rodrigues and Lima, 2011). (float and sink) were filtered and weighed to calculate the mass recovery. Finally, the products were homogenised, sampled and powdered to determine the whiteness, $\operatorname{CIE}\left(L^{*} a^{*} b^{*}\right)$ indices and chemical composition.

The leaching tests of the purified product, obtained using the optimised flotation condition for the $-74 \mu \mathrm{m}$ soapstone powder, were carried out using hydrochloric acid in the following conditions: $\mathrm{HCl}$ concentration $(2$ and $4 \mathrm{M})$, temperature $\left(50^{\circ} \mathrm{C}\right.$ and $\left.80^{\circ} \mathrm{C}\right)$ and leaching time ( 30 and $60 \mathrm{~min}$ ). Minitab 15 software was used to create and analyse the results of a planning factorial design with three factors (variables) on variable response whiteness. This analysis was performed on a total of 16 leaching tests.

Desliming operation for soapstone powder (fraction size $-74 \mu \mathrm{m}$ ) was carried out with the objective of avoiding the heterocoagulation of ultrafine particles $(<10 \mu \mathrm{m})$ of gangue minerals and talc, gangue ultrafine particles entraining in the concentrates and the slime coating of the gangue minerals by talc ultrafine particles and vice-versa (Sivamohan, 1990; Jameson et al.,

Table 1

Variables and their respective levels tested in the flotation tests.

\begin{tabular}{llc}
\hline Factors (variables) & Level \\
\cline { 2 - 3 } & Minimum & Maximum \\
\hline Kerosene (g/ton) & 500 & 1000 \\
Sodium metasilicate (g/ton) & 500 & 1000 \\
Methyl isobutyl carbinol - MIBC (g/ton) & 75 & 150 \\
Pulp pH & 7 & 11 \\
Pulp density (\%) & 10 & 20 \\
Cell speed (rpm) & 800 & 1200 \\
Kerosene conditioning time (min) & 5 & 10 \\
MIBC conditioning time (min) & 5 & 10 \\
\hline
\end{tabular}


2007). The desliming process consisted of the following steps. First, the soapstone powder was put into a $4 \mathrm{~L}$ cell cube. Then, a volume of water sufficient to obtain a pulp density of $15 \%$ was added, and the flotation cell (Cimaq) was turned on at an adjusted speed of $1200 \mathrm{rpm}$. After $3 \mathrm{~min}$, the flotation cell was turned off, and after $10 \mathrm{~min}$, the mud was removed. This operation was performed twice. Finally, the deslimed soapstone powder was dried at $105^{\circ} \mathrm{C}$.

The leaching tests of purified soapstone by flotation consisted of the following steps. First, a pulp of $15 \%$ density was prepared with deionised water. Then, the speed of a constant temperature magnetic stirrer (BiomiXer, model $78 \mathrm{HW}-1$ ) was adjusted to $640 \mathrm{rpm}$. The pulp was conditioned for $2 \mathrm{~min}$ at a temperature of $50{ }^{\circ} \mathrm{C}$ or $80^{\circ} \mathrm{C}$. After the pulp achieved the desired temperature $\left(50^{\circ} \mathrm{C}\right.$ or $80^{\circ} \mathrm{C}$ ), hydrochloric acid was added $(2$ or $4 \mathrm{M})$, and the pulp was submitted to constant stirring for the specified time (30 or $60 \mathrm{~min}$ ). The solids were then washed with deionised water, vacuum filtered with a Buchner funnel, dried at a temperature of $105{ }^{\circ} \mathrm{C}$, weighed, homogenised, quartered and powdered to determine the whiteness, CIE indices $\left(L^{*} a^{*} b^{*}\right)$ and chemical composition.

The whiteness and CIE indices $\left(L^{*} a^{*} b^{*}\right)$ of the soapstone powder $(+74 \mu \mathrm{m}$ and $-74 \mu \mathrm{m})$ and the purified talc were determined using a Technidyne Color Touch PC spectrometer. The samples were prepared for determination of the whiteness and CIE indices by powdering the sample in an orbital mill for $1 \mathrm{~min}$. Next, the material was homogenised and quartered to obtain a mass subsample of $10 \mathrm{~g}$ that was placed on a watch glass to dry at a temperature of $105{ }^{\circ} \mathrm{C}$. Then, a pellet of dried powder was made using a Powder Press Apparatus. To do this, the dried sample was transferred to a cylinder placed on a $2^{\prime \prime}$ square glass compression plate; the plunger was then placed onto the powder, and the mount was put into a powder press at 80 psi. Finally, the pellet was transferred to the spectrometer, and the whiteness and CIE indices $\left(L^{*} a^{*} b^{*}\right)$ were determined.

\section{Results and discussion}

\subsection{Size distribution and mineralogy}

Fig. 4 presents the size distribution of the soapstone powder residue obtained using wet sieving. Approximately $50 \%$ of the particles are under $74 \mu \mathrm{m}$, and approximately $27 \%$ of the particles are smaller than $37 \mu \mathrm{m}$. Thus, this material was classified in a 74$\mu \mathrm{m}$ aperture sieve for the concentration tests performed by magnetic separation (fraction size over $74 \mu \mathrm{m}$ ) and froth flotation (fraction size under $74 \mu \mathrm{m}$ ).

Fig. 5 presents the size distribution of the soapstone powder residue $(-74 \mu \mathrm{m})$, which was determined using laser diffraction (Cilas 1064). The $d_{10}$ of soapstone powder without desliming was $7 \mu \mathrm{m}$ and was $10 \mu \mathrm{m}$ for deslimed soapstone.

The minerals identified, with their respective $d$ values (basal spacing), in the X-ray patterns of all size fractions of soapstone

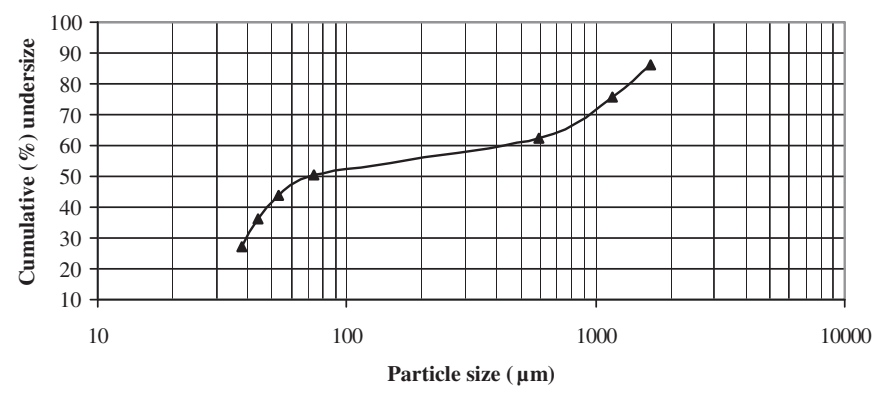

Fig. 4. Particle size distribution of soapstone powder residue.

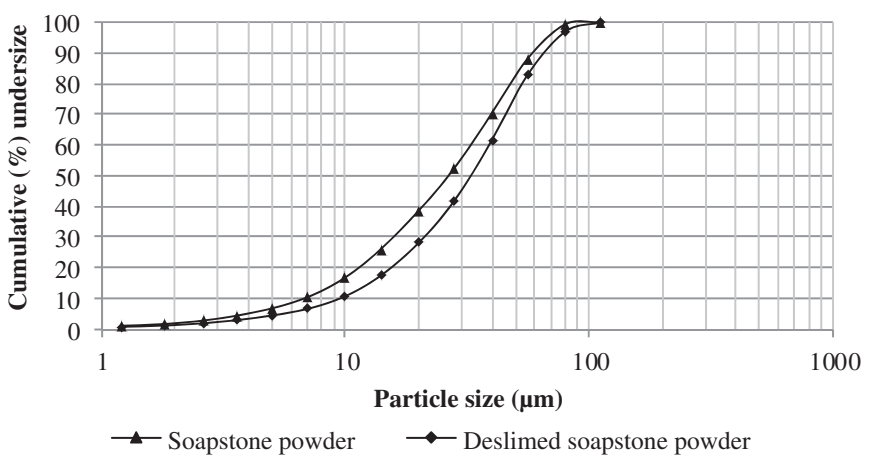

Fig. 5. Particle size distribution of soapstone powder residue $(-74 \mu \mathrm{m})$.

powder analysed, are listed as follows: talc (9.205; 3.1021; $4.641 ; 2.4826 ; 1.5550 ; 1.3881 \AA ̊$ A), kaolinite $(7.062 ; 3.7221 ; 3.5540$; $3.1021 ; 2.2261 ; 2.1874 ; 2.0035 ; 1.8067 ; 1.6702 ; 1.5550 \AA$ ), chlorite-serpentine $(13.94 ; 7.062 ; 4.641 ; 3.554 ; 2.8453 \AA)$, nimite (13.94; 7.062; 4.7156; 3.5540; $2.8453 \AA$ ); magnesite (2.8453; $2.3294 ; 2.0829 ; 1.3881 \AA$ ) and dolomite $(2.8453 ; 2.1874 ; 2.0035 \AA$ ). The minerals, sulphides (pyrite, arsenopyrite, pentlandite) and oxides (magnetite/hematite) were identified in soapstone from the Bandeiras region (Lima et al., 2009) but were not detected in the Xray patterns of the size fractions, probably due to the small proportion (less than $2 \%$ ) of these minerals in the subsamples analysed and the presence of several minerals, which can make mineral identification in the X-ray patterns difficult. The identified kaolinite mineral may be a result of orthoclase alteration, as identified by Lima et al. (2009).

\subsection{Purification tests in bench scale}

\subsubsection{Purification tests for the $+74 \mu \mathrm{m}$ sample}

Table 2 presents the mass recovery, whiteness and CIE indices of the feed and the purified products from the three magnetic separation tests performed using the $+74 \mu \mathrm{m}$ fraction size sample of soapstone powder in each test condition. Table 3 presents the average chemical composition and LOI of the feed and the purified products.

As can be observed in Table 2, the mass recovery of the soapstone residue varied from approximately 62-67\%. Piga and Maruzzo (1992) proposed a preconcentration step for an Italian talc ore containing chlorite, carbonates, magnetite and sulphides by low-intensity magnetic separation to remove the magnetite mineral before the flotation test, once the high intensity field conducted to very low recovery of talc.

The whiteness of the purified product in a $4900 \mathrm{G}$ field (Table 2) increased by $6 \%$ compared with the feed whiteness (59.72\%). This increase in whiteness is probably related to the removal of the iron oxides (magnetite, ilmenite and hematite) present in small proportions in this material. The CIE indices of the purified products did not change significantly in comparison with the feed CIE

Table 2

Mass recovery, whiteness and $\operatorname{CIE}\left(L^{*} a^{*} b^{*}\right)$ indices of purified (non-magnetic) product and feed (residues without ore dressing) for the $+74 \mu \mathrm{m}$ fraction size.

\begin{tabular}{lllllll}
\hline Purified product & Mass recovery (\%) & Whiteness (ISO) & \multicolumn{4}{l}{ CIE group } \\
\cline { 3 - 6 } & & & $L^{*}$ & $a^{*}$ & $b^{*}$ \\
\hline Feed & 100.00 & 59.72 & 89.10 & 0.58 & 8.05 \\
$3000 \mathrm{G}$ & 62.53 & 64.75 & 88.67 & 0.68 & 7.86 \\
$4300 \mathrm{G}$ & 62.39 & 65.22 & 89.00 & 0.70 & 8.00 \\
$4900 \mathrm{G}$ & 67.42 & 65.44 & 89.05 & 0.68 & 7.88 \\
\hline
\end{tabular}


Table 3

Chemical composition and loss on ignition (LOI) of non-magnetic (purified) products and feed (fraction size $+74 \mu \mathrm{m}$ ).

\begin{tabular}{|c|c|c|c|c|c|c|c|c|c|c|c|c|}
\hline \multirow[t]{3}{*}{ Purified product } & \multicolumn{12}{|c|}{ Content } \\
\hline & \multicolumn{5}{|l|}{ ppm } & \multicolumn{7}{|l|}{$\%$} \\
\hline & As & $\mathrm{Cu}$ & $\mathrm{Ni}$ & $\mathrm{Pb}$ & $\mathrm{Zn}$ & $\mathrm{Al}_{2} \mathrm{O}_{3}$ & $\mathrm{CaO}$ & $\mathrm{Fe}_{2} \mathrm{O}_{3}$ & $\mathrm{MgO}$ & $\mathrm{TiO}_{2}$ & $\mathrm{SiO}_{2}$ & LOI \\
\hline Feed & 11.1 & 9.59 & 1941 & $<8.3$ & 79.5 & 2.53 & 0.463 & 5.40 & 28.5 & 0.0642 & 57.5 & 6.01 \\
\hline $3000 \mathrm{G}$ & $<9.45$ & 7.57 & 1944 & $<8.3$ & 77 & 2.13 & 0.0554 & 3.78 & 30.4 & 0.0454 & 57.6 & 5.97 \\
\hline $4300 \mathrm{G}$ & $<9.45$ & 8.56 & 1965 & $<8.3$ & 68.6 & 2.12 & 0.049 & 3.86 & 29.8 & 0.0441 & 58.2 & 5.98 \\
\hline $4900 \mathrm{G}$ & $<9.45$ & 7.35 & 1977 & $<8.3$ & 67.7 & 2.14 & 0.0571 & 3.97 & 29.4 & 0.0426 & 58.5 & 5.9 \\
\hline
\end{tabular}

G- Gauss.

indices. In terms of whiteness, the feed and products purified by magnetic separation were within the specifications for paper filler (wallpaper and packaging - whiteness ISO of 54-75\%) (Pontes and Almeida, 2008). The value of whiteness obtained and the chemical composition of the purified product (Table 3) are nearly within paint industry specifications (Pontes and Almeida, 2008). Based on these results, it is possible to recover $100 \%$ of the $+74 \mu \mathrm{m}$ residues for use as filler in the paper industry, representing a total recovery of $70 \%$ of the exploited rock. For the paint industry, the recoveries of $62-67 \%$ observed in the non-magnetic product correspond to an $18-20 \%$ increase in the global recovery (40\%) of exploited soapstone for dimension stone and artisan workshops.

\subsubsection{Purification tests for the $-74 \mu \mathrm{m}$ sample}

The Pareto's chart and surface plots of the studied effects on the mass recovery and whiteness of the flotation tests conducted with soapstone powder (fraction size $-74 \mu \mathrm{m}$ ) are presented in Figs. 6-9.

As can be observed in Fig. 6, among the studied effects, only the pulp density and the MIBC dosage were significant for mass recovery. In the case of whiteness, only the pulp density was significant (Fig. 7). The mass recoveries were higher when the pulp densities and MIBC dosages were higher (Fig. 8). The opposite occurred for whiteness (Fig. 9). After the optimisation of the factorial planning experimental design using Minitab 15 for a target of $80 \%$ mass recovery and $77 \%$ whiteness ISO, the optimised response was obtained using a pulp density of $14 \%$, an MIBC dosage of $150 \mathrm{~g} /$ ton and a kerosene dosage of $500 \mathrm{~g} /$ ton. In this case, the predicted values of the mass recovery and whiteness were $80 \%$ and $64 \%$, respectively. Thus, the flotation tests in the bench with soapstone powder, without and with desliming, were conducted under the optimised conditions for the significant effects (pulp

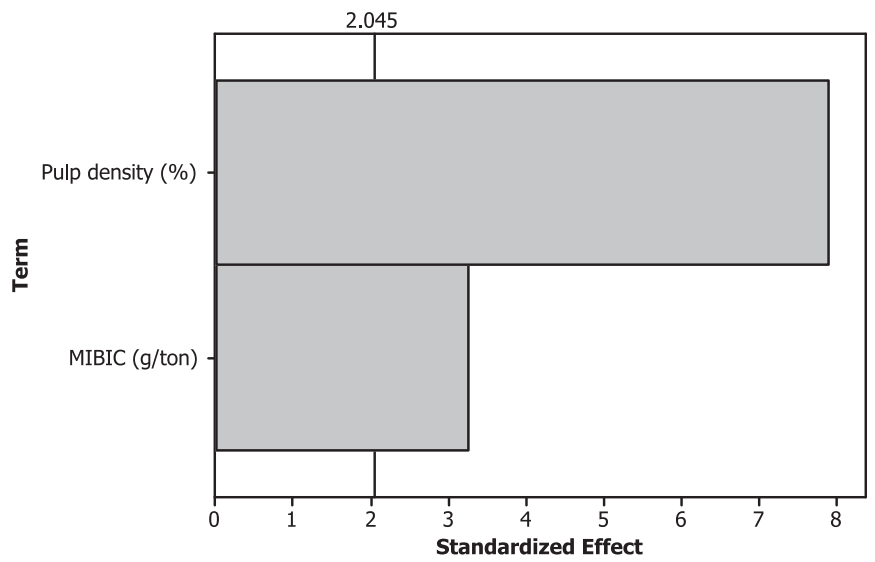

Fig. 6. Pareto's chart (alpha $=0.05$ ) of standardised effects on the mass recovery of purified talc by flotation (rougher step) of soapstone powder $(-74 \mu \mathrm{m})$ without desliming. density of $14 \%$ and MIBC dosage of $150 \mathrm{~g} /$ ton). All others effects were fixed at their minimum values (sodium metassilicate $=500 \mathrm{~g}$ / ton, $\mathrm{pH}=7$, cell speed $=800 \mathrm{rpm}$, kerosene and MIBC conditioning time $=5 \mathrm{~min}$ ). For a mixing of four talc ores from the Eastern Desert of Egypt (Shalatin area) (tremolite-talc-chlorite-shist; antigorite-serpentine; talc-shist and talc-chlorite-shist), the optimum conditions of the flotation tests were obtained at $\mathrm{pH} 11$, a depressant dosage (sodium hexametaphosphate) of $1 \mathrm{~kg} / \mathrm{ton}$, a collector dosage (oleic acid in an equal mixture with kerosene) of $1.2 \mathrm{~kg} /$ ton and a pulp density of $200 \mathrm{~g} \mathrm{~L}^{-1}$ ( $\sim 18 \%$ ) (Ahmed et al., $2007)$. For a representative talc sample composed of magnesite (36.47\%), talc (48.69\%), serpentine (2.41\%), dolomite (9.63\%), and quartz $(2.47 \%)$ from the Wadi El-Barramiya region in the Eastern Desert of Egypt, the optimum pH for natural talc floatability was neutral (Yehia and Al-Wakell, 2000).

Afterwards, a leaching study of the purified talc from the optimised flotation test was conducted with $\mathrm{HCl}$ using a factorial planning design. The Pareto's chart and surface plots of the studied effects ( $\mathrm{HCl}$ dosage and leaching temperature) on whiteness, carried out with the purified rougher flotation product of soapstone powder (fraction size $-74 \mu \mathrm{m}$ ) without desliming, are presented in Figs. 10-12.

As can be observed in the Pareto's chart (Fig. 10), all of the studied effects were significant in the whiteness response variable. The surface plots (Figs. 11 and 12) show that the whiteness was higher (84\%) for a dosage of $4 \mathrm{M}$ of $\mathrm{HCl}$, a temperature of $80{ }^{\circ} \mathrm{C}$ and a time of 60 min of leaching (Fig. 12), which was confirmed as the optimised condition for the levels of the studied variables, using the optimisation tool in Minitab 15 software. This result indicates a gain of $20.5 \%$ compared with the rougher purified flotation product (whiteness of 63.5\%). An Argentine talc ore concentrate, with 10-20\% carbonates (magnesite, dolomite and calcite) with an

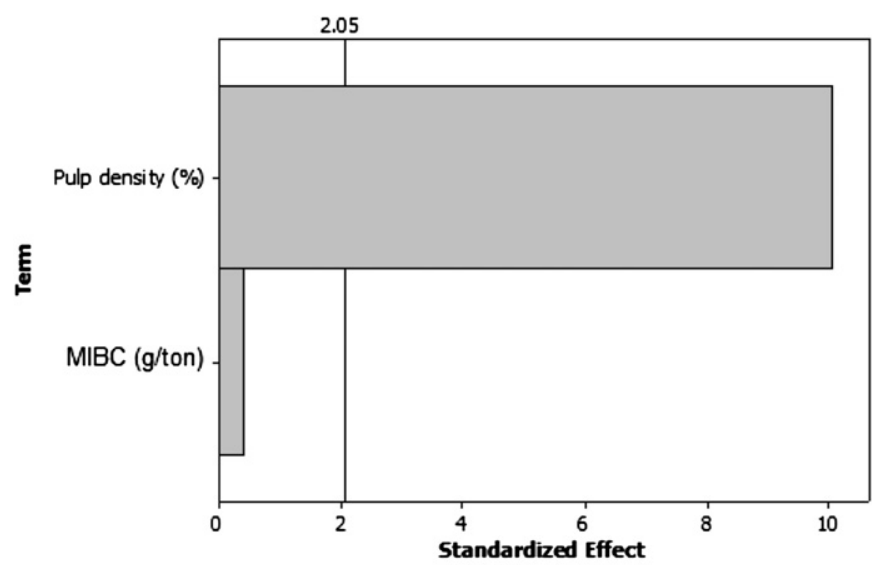

Fig. 7. Pareto's chart (alpha $=0.05$ ) of standardised effects on the whiteness of purified talc by flotation (rougher step) of the soapstone powder $(-74 \mu \mathrm{m})$ without desliming. 


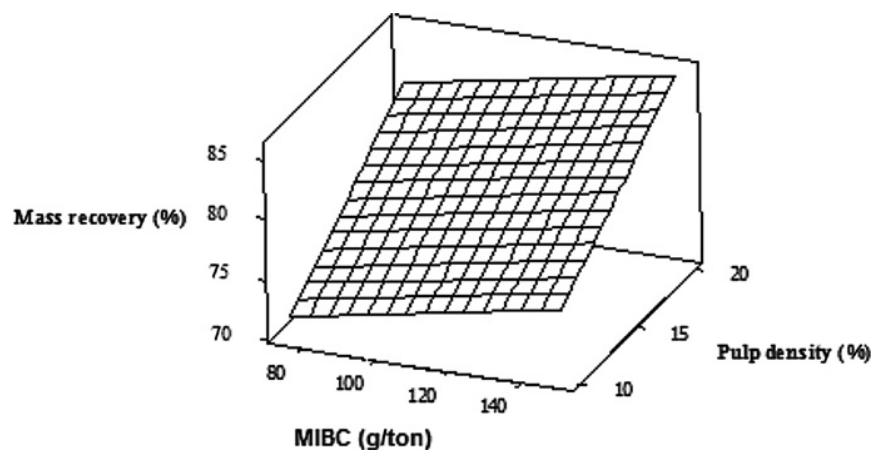

Fig. 8. Mass recovery surface plot of purified talc by flotation (rougher step) of the soapstone powder $(-74 \mu \mathrm{m})$ as a function of the MIBC dosage and pulp density without desliming.

initial whiteness of $65.5 \%$, exhibited an increase of $4-7 \%$ after leaching with hydrochloric acid (concentration of 25-100\%) (Sarquis and Gonzalez, 1998). Table 4 presents the results of all purification tests of soapstone powder (fraction size $-74 \mu \mathrm{m}$ ) performed in the optimised conditions.

As can be observed in Table 4 , the mass recovery under the experimental optimised conditions was approximately $7 \%$ higher than the optimised value predicted using Minitab 15 (80\%), and the whiteness (63.5\%) was slightly lower than the optimised value (64.2\%) predicted using Minitab 15. In this case, an increase of $12 \%$ was observed in the whiteness of the soapstone residue compared with the feed whiteness (51.34\%). This result represents the possibility of obtaining an increase of approximately $25 \%$ of the global recovery of the exploited soapstone. After two cleaner flotation tests, a product with a whiteness of $68.7 \%$ was obtained, which represents an increase of 5\% in whiteness compared with the experimental rougher test. However, the mass recovery decreased by approximately 23\%. The increase of whiteness obtained with the two cleaning steps was not enough to justify these steps, once the whiteness obtained is just within the specifications for filler paper as the rougher purified product, despite the whiteness gain.

After desliming the soapstone residue (fraction size $-74 \mu \mathrm{m}$ ), the whiteness of the product was $59 \%$ (Table 4 ), an increase of $8 \%$ compared with the feed whiteness (51.34\%). The mass discharged in this case was only $6 \mathrm{wt} \%$. With this value of whiteness, the fraction size $-74 \mu \mathrm{m}(51.34 \%)$ could be applied only in the insecticide filler. After desliming, $94 \mathrm{wt} \%$ of this material could be applied as filler paper, which means approximately 30\% and 28\% global soapstone recovery for application in the insecticide and

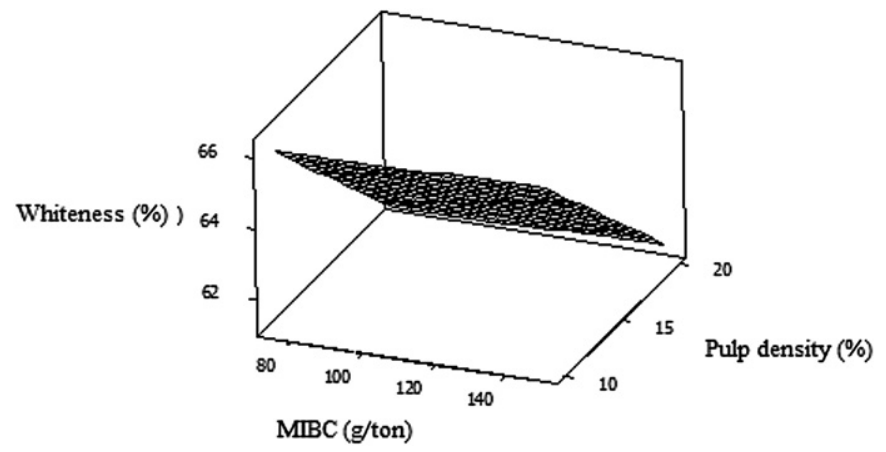

Fig. 9. Whiteness surface plot of purified talc by flotation (rougher step) of the soapstone powder $(-74 \mu \mathrm{m})$ as a function of MIBC dosage and pulp density without desliming.

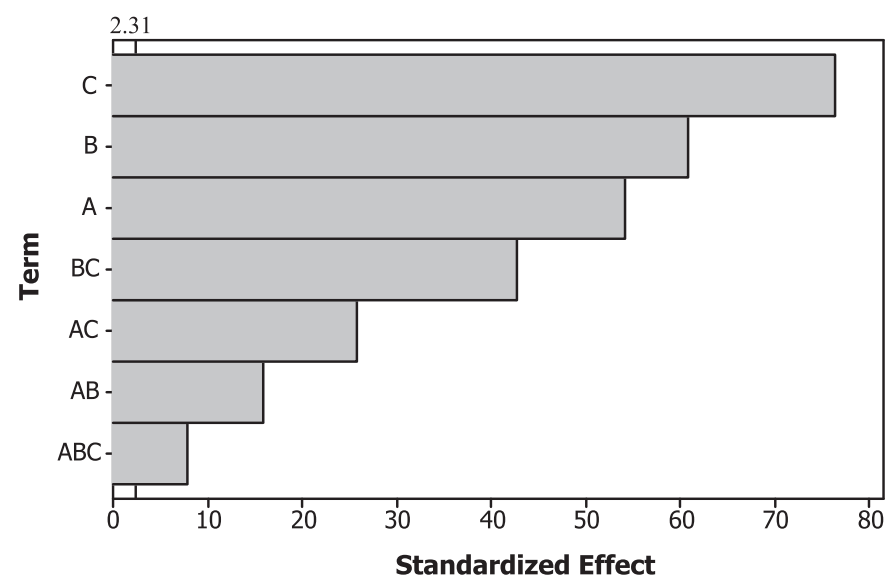

Fig. 10. Pareto's chart (alpha $=0.05$ ) of standardised effects on whiteness leaching of purified talc of rougher flotation without desliming $(\mathrm{A}-\mathrm{HCl}$ dosage; $\mathrm{B}-$ temperature; C - time).

paper industries, respectively. The mass recovery of the rougher purified product was $81 \%$ of the global residue $(-74 \mu \mathrm{m})$, and the whiteness obtained was $67 \%$, which is approximately $3.5 \%$ higher than that of the rougher purified product without desliming (Table 4); after two cleaning steps, it was approximately $71 \%$. As in the previous case, a product with specifications within those for paper filler and paint was obtained once the particles were lamellar and the oil absorption was 28.5 (g/100 g) (Rodrigues and Lima, 2011). Despite the whiteness gained in the cleaning steps, the cleaning steps are not justified because the mass recovery drops drastically and the whiteness of obtained product is not enough for more valuable use.

As can be seen in Table 4 , the values of lightness $\left(L^{*}\right)$ increase and the values of redness $\left(a^{*}\right)$ and yellowness $\left(b^{*}\right)$ decrease from rougher concentrate to leached product. Thus, by observing the chemical compositions of all purified products (presented in Table 5), the contents of $\mathrm{Fe}_{2} \mathrm{O}_{3}, \mathrm{Al}_{2} \mathrm{O}_{3}, \mathrm{TiO}_{2}, \mathrm{CaO}, \mathrm{LOI}, \mathrm{Cu}$ and $\mathrm{Zn}$ in the rougher and cleaner flotation concentrate products decreased compared with the feed, which is consistent with the whiteness and lightness of these purified products. These decreases are probably related to the partial removal of the gangue minerals (sulphides, oxides, carbonates, chlinoclore, chlorite-serpentine and nimite), identified in this material by Lima et al. (2009).

Higher whiteness $(\sim 84 \%)$ and a decrease in the indices $a^{*}$ (redness) and $b^{*}$ (yellowness) were observed in the leaching product compared to the flotation concentrates (Table 4). The $\mathrm{SiO}_{2}$ assay increased to $60.3 \%$ and the $\mathrm{Fe}_{2} \mathrm{O}_{3}$ assay decreased to $3.42 \%$. The final product, after leaching the flotation concentrate of Egyptian talc ore with diluted hydrochloric acid (10\%), showed an

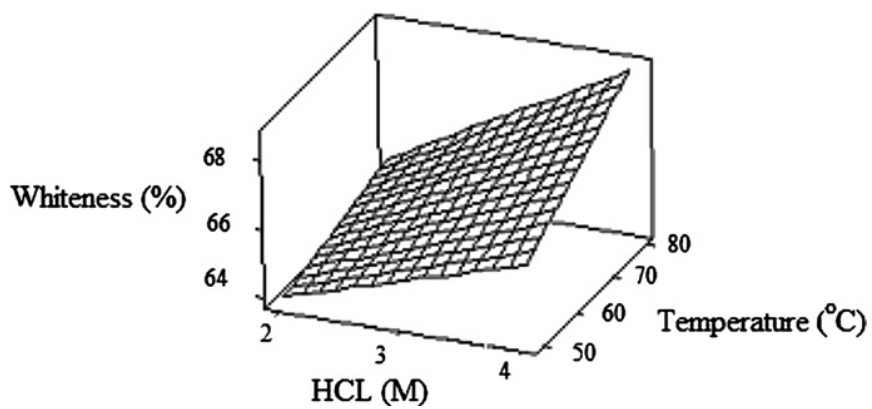

Fig. 11. Whiteness surface plot of the purified talc as a function of the $\mathrm{HCl}$ dosage and leaching temperature for $30 \mathrm{~min}$. 
Table 4

Mass recovery, whiteness and CIE indices of purified products under the optimised conditions (froth flotation and leaching with $\mathrm{HCl}$ ) and feed (fraction size $-74 \mu \mathrm{m}$ ).

\begin{tabular}{|c|c|c|c|c|c|}
\hline \multirow[t]{2}{*}{ Product } & \multirow[t]{2}{*}{ Mass recovery (\%) } & \multirow[t]{2}{*}{ Whiteness (ISO) } & \multicolumn{3}{|c|}{ CIE indices } \\
\hline & & & $L^{*}$ & $a^{*}$ & $b^{*}$ \\
\hline Rougher concentrate & 86.65 & 63.45 & 88.82 & 1.27 & 9.30 \\
\hline Second cleaner concentrate & 64.01 & 68.34 & 90.46 & 1.02 & 7.59 \\
\hline Deslimed rougher concentrate & 81.00 & 67.21 & 89.85 & 0.75 & 7.71 \\
\hline Second deslimed cleaner concentrate & 60.85 & 70.77 & 91.49 & 0.76 & 7.38 \\
\hline Leaching product & - & 83.99 & 94.62 & -0.11 & 2.22 \\
\hline Feed $(-74 \mu \mathrm{m})$ & 100.00 & 51.34 & 81.92 & 0.54 & 9.14 \\
\hline Deslimed feed $(-74 \mu \mathrm{m})$ & 94.00 & 59.03 & 87.14 & 1.54 & 10.55 \\
\hline
\end{tabular}

Table 5

Chemical compositions and LOI of feed and all optimised purified products (fraction size $-74 \mu \mathrm{m}$ ).

\begin{tabular}{|c|c|c|c|c|c|c|c|c|c|c|c|c|}
\hline \multirow[t]{3}{*}{ Product } & \multicolumn{12}{|c|}{ Content } \\
\hline & \multicolumn{7}{|l|}{$(\%)$} & \multicolumn{5}{|c|}{$(\mathrm{ppm})$} \\
\hline & $\mathrm{MgO}$ & $\mathrm{SiO}_{2}$ & $\mathrm{Al}_{2} \mathrm{O}_{3}$ & $\mathrm{CaO}$ & $\mathrm{Fe}_{2} \mathrm{O}_{3}$ & $\mathrm{TiO}_{2}$ & LOI & $\mathrm{Ni}$ & $\mathrm{Cu}$ & $\mathrm{Pb}$ & $\mathrm{Zn}$ & As \\
\hline Feed $(-74 \mu \mathrm{m})$ & 27.7 & 59.2 & 2.27 & 0.0580 & 4.70 & 0.0513 & 5.98 & 1956 & 13.4 & $<8.30$ & 85.8 & 11.1 \\
\hline Rougher concentrate & 28.3 & 61.1 & 1.21 & 0.0260 & 4.00 & 0.0383 & 5.27 & 2096 & 3.45 & $<8.30$ & 67.0 & $<9.45$ \\
\hline Second cleaner concentrate & 27.7 & 62.7 & 0.767 & 0.018 & 3.57 & 0.0304 & 5.20 & 2126 & 0.926 & 8.80 & 64.4 & $<9.45$ \\
\hline Deslimed rougher concentrate & 27.9 & 61.7 & 0.99 & 0.0247 & 4.03 & 0.0432 & 5.33 & 2089 & 1.80 & $<8.30$ & 68.0 & $<9.45$ \\
\hline Second deslimed cleaner concentrate & 29.1 & 61.3 & 0.805 & 0.0157 & 3.57 & 0.0328 & 5.16 & 2097 & 2.09 & 10.20 & 62.4 & $<9.45$ \\
\hline Leaching product & 30.0 & 60.3 & 0.951 & 0.0207 & 3.42 & 0.0343 & 5.21 & 1916 & 6.60 & $<8.30$ & 58.9 & $<9.45$ \\
\hline
\end{tabular}

increase in the $\mathrm{SiO}_{2}$ assay and a decrease in the $\mathrm{Fe}_{2} \mathrm{O}_{3}$ assay (Ahmed et al., 2007).

In terms of the chemical composition of the leaching product presented in Table 5, it can be observed that all impurities, except the $\mathrm{Cu}$ grade, were smaller in the leaching product than in the purified rougher flotation product. The opposite was observed with $\mathrm{MgO}$.

Castillo et al. (2011), using XRD and FTIR (Fourier Transform Infrared Spectroscopy), identified the following minerals in a talc sample: talc, chlorite, dolomite, calcite and magnesite. After leaching this sample with hydrochloric acid, they observed a decrease in the $\mathrm{Fe}_{2} \mathrm{O}_{3}$ assay and loss on ignition assay, which was attributed to the removal of chlorite and carbonates from the sample, evidenced by the fact that the peaks assigned to these minerals in the X-ray pattern and the infrared spectrum disappeared. $\mathrm{SiO}_{2}$ and $\mathrm{MgO}$ are the main constituents of talc $\left.\left(\mathrm{Mg}_{3}\left(\mathrm{SiO}_{4}\right)_{10}\right)(\mathrm{OH})_{2}\right)$; thus, the increase in $\mathrm{MgO}$ content in the leached product is related to the increased proportion of talc and is mainly due to the removal of chlorite and carbonate by hydrochloric acid. Therefore, based on the chemical composition, whiteness (83.99\%) and CIE indices $\left(L^{*}=94.62 ; a^{*}=-0.11\right.$ and $b^{*}=2.22$ ) that were obtained for the leaching product, this purified product achieved the necessary specifications for use in the paint, paper (filler), insecticide, textile and plastic industries.

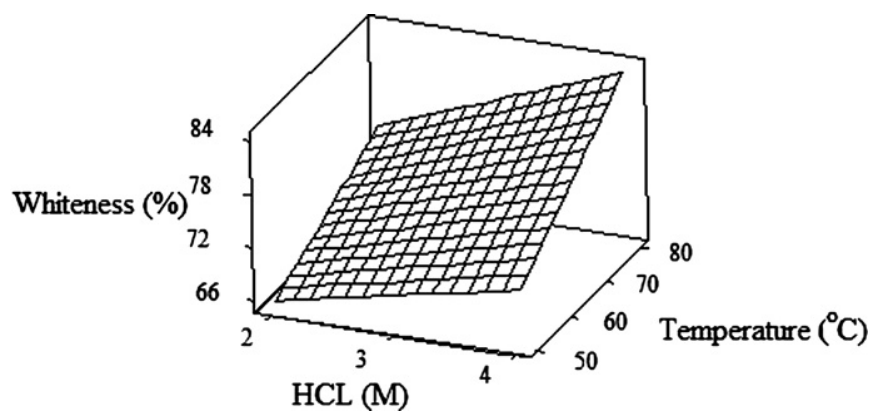

Fig. 12. Whiteness surface plot of the purified talc as a function of $\mathrm{HCl}$ dosage and leaching temperature for $60 \mathrm{~min}$.

\section{Conclusion}

The studies conducted using soapstone powder from the Bandeiras region of Santa Rita de Ouro Preto show that approximately $50 \%$ of the particles are smaller than $74 \mu \mathrm{m}$ and approximately $27 \%$ are smaller than $37 \mu \mathrm{m}$. The identified minerals, in all fraction sizes, were as follows: talc, kaolinite, chlorite-serpentine, magnesite, dolomite and nimite. Sulphides and oxides were not identified, probably due to their small proportion in the subsamples analysed and the presence of several minerals, which can make mineral identification in the X-ray patterns difficult. It is possible to recover $100 \%$ of the soapstone residue for use as insecticide filler. The fraction size above $74 \mu \mathrm{m}$ can be used in the paper industry (wallpaper and packaging). The same application is possible for fraction sizes $-74 \mu \mathrm{m}$ after desliming (mass recovery of $94 \%$ ). For the paint industry, it is necessary to purify the residues using magnetic separation (mass recovery of $67 \%$ for fraction size above $74 \mu \mathrm{m}$ ) and flotation (mass recovery above $80 \%$ for fraction size below $74 \mu \mathrm{m}$ ). For more valuable applications, such as usage in the plastic industry, the material must be leached by hydrochloric acid.

\section{Acknowledgements}

Financial support from FAPEMIG and CNPq for scholarships for the authors is gratefully acknowledged. The authors are grateful to reviewers.

\section{List of symbols}

$\begin{array}{ll}L^{*} & \text { lightness } \\ a^{*} & \text { redness } \\ b^{*} & \text { yellowness } \\ \text { LOI } & \text { loss on ignition } \\ \text { MIBC } & \text { metyl isobutyl carbinol } \\ \text { G } & \text { Gauss } \\ \text { M } & \text { molar } \\ \text { L } & \text { liter } \\ \text { mL } & \text { milliliter }\end{array}$




$\begin{array}{ll}\mathrm{ppm} & \text { part per million } \\ \mathrm{g} / \mathrm{ton} & \begin{array}{l}\text { gram per ton } \\ \mathrm{MPa}\end{array} \\ \mathrm{meg} & \text { poupascal } \\ \mathrm{psi} & \text { pound per square inch } \\ \mu \mathrm{m} & \text { angstrom }\left(10^{-8} \mathrm{~m}\right) \\ { }^{\circ} \mathrm{C} & \text { micrometer } \\ \mathrm{rpm} & \text { degree centigrade } \\ \text { min } & \text { rotations per minute } \\ \end{array}$

\section{References}

Ahmed, M.M., Ibrahim, G.A., Hassan, M.M.A., 2007. Improvement of Egyptian talc quality for industrial uses by flotation process and leaching. International Journal of Mineral Processing 83, 132-145.

Casanova, H., Orrego, J.A., Zapata, J., 2007. Oil absorption of talc minerals and dispersant demand of talc mineral non-aqueous dispersions as a function of talc content: a surface chemistry approach. Colloids and Surfaces A: Physicochemical and Engineering Aspects 299, 38-44.

Castillo, L.A., Barbosa, S.E., Maiza, P., Capiati, N.J., 2011. Surface modifications of talcs: effects of inorganic and organic acid treatments. Journal of Material Science 46, 2578-2586.

Driussi, C., Jansz, J., 2006. Technological options for waste minimization in mining industry. Journal of Cleaner Production 14, 682-688.

Jameson, G.J., Nguyen, A.V., Ata, S., 2007. The flotation of fine and coarse particles. In: Fuerstenau, M.C., Jameson, G., Yoon, R. (Eds.), Froth Flotation: A Century of Innovation, pp. 339-372.

Kuzvart, M., 1984. Industrial Minerals and Rocks. Elsevier, Amsterdam, pp. $252-262$.

Lara Filho, J., 1997. Geologia do Talco e Pirofilita. In: DNPM/CPRM. Principais Depósitos Minerais do Brasil, vol. IV(part C), pp. 529-544.

Lima, R.M.F., Braga, D.M., Silva, F.B.R., 2009. Technological characterization of soapstone from Santa Rita de Ouro Preto/Brazil. In: Proceedings of Fifth International Materials Symposium. Recent Advances in Characterization Processing,
Design and Modelling of Structural and Functional Materials. Sociedade Portuguesa de Materiais, Lisbon, Portugal, p. 8.

Nkoumbou, C., Villiaras, F., Njopwouo, D., Ngoune, C.Y., Barres, O., Pelletier, M. Razafitianamaharavo, A., Yvon, J., 2008. Physicochemical properties of talc ore from three deposits on Lamal Pougue area (Yaoundle Pan-African Belt, Cameroon) in relation to industrial uses. Applied Clay Science 41, 113-132.

Piga, L., Maruzzo, G., 1992. Preconcentration of an Italian talc by magnetic separation and attrition. International Journal of Mineral Processing 35, 291-297.

Pinheiro, J.C.F., 1973. Perfil Analítico do Talco, Boletim No. 22. DNPM, p. 41.

Pogrebenkove, V.M., Sedel'nikova, B.M., Vereshchagin, V.I., 1997. Talc-based ceramic pigments. Glass and Ceramics $54(11-12), 351-353$.

Pontes, I.F., Almeida, S.L.M., 2008. Talco. In: Luz, A.B., Lins, F.F. (Eds.), Rochas e minerais industriais usos e especificações. CETEM/MCT, Rio de Janeiro, pp. 607-628

Rodrigues, M.L.M., 2010. Caracterização tecnológica de resíduos de pedra-sabão de oficinas de artesanato em pedra-sabão da região de Ouro Preto. Ouro Preto: Programa de Pós-Graduação em Engenharia Mineral, Universidade Federal de Ouro Preto (Master dissertation). p. 120.

Rodrigues, M.L.M., Lima, R.M.F., 2011. Purificação de Resíduos de Oficina de Artesanato em Pedra-Sabão por Flotação e Alvejamento Químico. REM: Revista Escola de Minas, Ouro Preto 64 (3), 357-361.

Roe, L.A., 1975. Talc and pyrophyllite. In: Industrial Minerals and Rock. American Institute of Mining Metallurgical and Petroleum Engineers Inc., Baltimore, Maryland, pp. 1127-1147. Printed in United States of America by Port City Press.

Santos, R.C.P., 2009. Análise dos entraves para a criação de um arranjo produtivo local (APL) de base mineral da pedra-sabão na região de Ouro Preto, Minas Gerais. Ouro Preto: Programa de Pós-Graduação em Engenharia Mineral Universidade Federal de Ouro Preto (Master dissertation). p. 92.

Sarquis, P.E., Gonzalez, M., 1998. Limits of the use of industrial talc - The carbonate effect. Minerals Engineering 11 (7), 657-660.

Sivamohan, R., 1990. The problem of recovering very fine particles in mineral processing - A review. International Journal of Mineral Processing 28 247-288.

Skinner, H.C.W., Foord, E.E., Mason, B., Rosenzweig, A., 1997. Pyrophylite talc group. In: Dana's New Mineralogy. Jhon Wiley \& Sons, Inc., England, pp. 1437-1444.

Yehia, A., Al-Wakell, M.I., 2000. Talc separation from talc-carbonate ore to be suitable for different industrial applications. Minerals Engineering 13 (1) 111-116. 